\title{
Performance and blood metabolites of growing pigs fed Paniculum miliaceum diet
}

\author{
Nicoleta Aurelia Lefter ${ }^{1}$, Mihaela Hăbeanuํㅜ, Anca Gheorghe ${ }^{1}$ \\ Lavinia Idriceanu ${ }^{1}$ \\ *corresponding author: nicoleta.ciuca@ibna.ro
}

${ }^{1}$ National Research and Development Institute for Animal Biology and Nutrition, Laboratory of Animal Nutrition, Balotesti, Calea Bucuresti no. 1, 077015, Ilfov, Romania.

\section{ABSTRACT}

During 30 days, the effects of millet grain regimen on performance indicators and blood metabolites in growing pigs were studied. A total of 40 Topigs pigs with similar age $(81 \pm 3 \mathrm{~d})$ and weight $(13.58 \pm 0.36 \mathrm{~kg})$ were divided into two groups: control (C), based on the corn-triticale (25\%)soybean meal and experimental (M, where the millet replaces triticale). The production parameters and plasma samples were evaluated at the end of the experiment. Spotchem EZ SP-4430 analyzer from Arkray-Japan was used to assess the blood lipid, protein, enzyme, and mineral profiles. We noticed that the $\mathrm{M}$ diet maintains appropriate performance $(33.22$ vs. 31.30 final BW; 0.646 vs. 0.608 average daily gain; 1.39 vs. 1.29 average daily feed intake and, respectively 0.46 vs. 0.47 Gain: Feed ratio) and plasma metabolic profile with the $\mathrm{C}$ diet $(\mathrm{P}>0.05)$. In conclusion, the $25 \%$ millet added to the growing pigs' diet did not affect the performance indicators or body health.

Keywords: growing pigs, millet grain, performance, plasma, health status

\section{INTRODUCTION}

Millets is a type of grain that belongs to the Gramineae family and it is also one of the earliest cultivated crops on the planet (Hassan et al., 2021). Several factors contribute to the growing interest in this ancient cereal as food and feed.

First of all, millet manifesting remarkable drought and cold tolerance and require minimal inputs; thus is perfectly suitable for marginal areas and could be considered a more environmentally friendly feedstuff ( $\mathrm{Lu}$ et al., 2009; Singh and Chauhan, 2019; Mathanghi et al., 2020).

In this line, recently, proso millet has been classified by the UN Food and Agriculture Organization as a $\mathrm{C} 4$ cereal because it takes more $\mathrm{CO}_{2}$ from the atmosphere and transforms it into oxygen (Mathanghi et al., 2020). 
Nevertheless, millet has resistance to pests and disease (Dipnarayan et al., 2016).

Consequently, millet could represent a potential feed source for local Romanian communities, particularly in areas that are characterized by a combination of the above-listed stress factors, where the commonly grown cereal (e.g., corn, triticale) become too marginal and unproductive.

Another attractive aspect is micronutrient richness, which provides a variety of health advantages, including a protective effect against various organs injury (Nishizawa et al., 2009). Furthermore, improved glucose and lipid metabolism (Whittaker et al., 2017) and reduced inflammation and energy homeostasis (Scherer, 2006). It has been observed that a millet diet can improve the nutritional status of malnourished pigs and maintain health (Li et al., 2019).

Nevertheless, recent works (Hăbeanu et al., 2019; Nishizawa et al., 2009; Li et al., 2019) stated that there is not enough research material published and available on the effect of millet grain on pigs health markers as an important requirement for ensuring the quality of pigs; thus, many aspects are necessary.

Generally, the high health status of growing pigs promotes productivity and efficiency. Therefore, it is also essential to know how this category of animals responds to the dietary nutrients beyond diet formulation.

The components of blood play essential functions in living systems and, thus, evaluation of blood parameters provides necessary information about the function of certain tissues and organs (Hellwing et al., 2007; Luo et al., 2016). Assessing plasma profiles might be a simple way to get valuable information regarding the effect of different nutritional regimens used in animal feeding, such as millet-based diets (Radostits et al., 2000; Schwartz and Conley, 2020).

The research aim was to evaluate the influence of replacing triticale with millet (Panicum miliaceum cv. Marius) in growing pigs on performance and blood profile.

\section{MATERIALS AND METHODS}

\section{Animal ethics}

The dietary test was conducted at the National Research Development Institute for Animal Biology and Nutrition, Balotesti, Romania, research farm. Applying the European legislation (Directive 2010/63/EU), the ethics committee at the institute accepted the procedures used in this trial (No. 1493/2018). 


\section{Animals and diets}

The study was conducted for 30 days on 40 hybrid Topigs pigs. The growing pigs aged $81 \pm 3$ days. Their initial average body weight (BW) was $13.58 \mathrm{~kg} \pm 0.36$. According to their BW, two homogenous experimental groups of $\mathrm{n}=20$ piglets/group with 10 pigs per replicate were formed. The control pigs (C) were fed on a basal diet with triticale (25\%)-corn-soybean meal, while the experimental group of pigs (M) contained a diet where grain millet replaced total triticale. Table 1 reports the composition of the experimental diets.

Table 1. Feed composition and nutrient content (as-fed basis)

\begin{tabular}{|c|c|c|}
\hline Items (g/kg) & C & M \\
\hline Corn & 358.3 & 344.9 \\
\hline Triticale & 250.0 & - \\
\hline Millet (cv. Marius) & - & 250.0 \\
\hline Rice meal & 150.0 & 150.0 \\
\hline Soybean meal & 100.0 & 100.0 \\
\hline Sunflower meal & 50.0 & 50.0 \\
\hline Corn gluten meal & 20.0 & 30.0 \\
\hline Milk powder & 30.0 & 30.0 \\
\hline Soybean oil & 7.0 & 5.0 \\
\hline DL-methionine & - & 0.6 \\
\hline L-Lysine $\mathrm{HCl}$ & 3.4 & 4.0 \\
\hline Calcium carbonate & 17.8 & 14.6 \\
\hline Monocalcium phosphate & 0.4 & 7.8 \\
\hline Salt & 2.0 & 2.0 \\
\hline Phytase & 0.1 & 0.1 \\
\hline Choline HCl premix & 1.0 & 1.0 \\
\hline Vitamin-mineral premix ${ }^{1}$ & 10.0 & 10.0 \\
\hline \multicolumn{3}{|l|}{ Calculated Nutrient's (g/kg) } \\
\hline Metabolisable energy $(\mathrm{MJ} / \mathrm{kg})^{2}$ & 12.67 & 12.63 \\
\hline Crude protein, total & 170.7 & 170.7 \\
\hline Crude protein, digestible & 133.7 & 133.4 \\
\hline Lysine, total & 10.5 & 10.5 \\
\hline Lysine, digestible & 8.7 & 8.9 \\
\hline Methionine + cysteine, total & 6.7 & 6.7 \\
\hline Methionine + cysteine, digestible & 5.3 & 5.4 \\
\hline Calcium & 9.0 & 9.0 \\
\hline Phosphorus, total & 7.0 & 7.0 \\
\hline Crude fibre & 46.6 & 47.4 \\
\hline
\end{tabular}

Note: ${ }^{1}(1 \%)$ Vitamin-mineral premix which contained: 10000 IU vit. A; 2000 IU vit. D; 30 IU vit. E; 3 mg vit. $K_{3} ; 2$ mg vit. $B_{1} ; 6$ mg vit. $B_{2} ; 20$ mg vit. $B_{3} ; 13.5 \mathrm{mg}$ vit. $B_{5} ; 3 \mathrm{mg}$ vit. $B_{6} ; 0.06 \mathrm{mg}$ vit. $B_{7} ; 0.8 \mathrm{mg}$ vit. B9; 0.05 mg vit. B12; 10 mg vit. C; 30 mg Mn; 110 mg Fe; 25 mg Cu; 100 mg Zn; 0.38 mg I; 0.36 mg 
Se; $0.3 \mathrm{mg}$ Co; $60 \mathrm{mg}$ antioxidant and corn starch as carrier. ${ }^{2}$ Metabolizable energy was calculated using regression equations (NRC, 2012). ${ }^{3}$ Diets: C-standard diet; M-experimental diet.

The amounts of energy and protein in both diets were equally. Both diets contained the same content of limiting amino acids (lysine, methionine + cysteine) and essential minerals (calcium and phosphorus). The diets were given in the granule form. Water and feed were provided on an ad libitum basis. Two meals per day at 8:00 and 13:00 $\mathrm{h}$ were given to the pigs. The feed intake (FI) was registered every day by measuring the amount of feed given and leftover. To evaluate performance (BW; average daily feed intake, ADFI; average daily gain, ADG; F: G ratio, feed: gain ratio) the pigs were weighed at the beginning and at day 30 after the experiment started.

\section{Blood analyses}

To assess the nutritional treatment's impact on animal health, at the end of the experimental period, the samples of blood were harvested by jugular venipuncture of 10 pigs per group in plastic tubes $(6 \mathrm{ml})$ with lithium heparin anticoagulant. Subsequent, centrifugation (3000 $\times \mathrm{g}$ for $15 \mathrm{~min})$ was used to separate the plasma, and the supernatant was retained at $-20^{\circ} \mathrm{C}$ until the analyses were carried out. The biochemical characteristics of the circulating blood - TG (triglycerides), T-Chol (total cholesterol), HDL-C (high-density lipoprotein cholesterol), T-Pro (total protein), Alb (albumin), UA (uric acid), Cre (creatinine), T-Bil (total bilirubin), BUN (urea nitrogen), AST (aspartate aminotransferase), ALT (alanine aminotransferase), LDH (lactate dehydrogenase) and CK (creatine kinase), GGT (gamma glutamyl-transferase), Ca (calcium), Mg (magnesium), IP (inorganic phosphorus) were performed using a laboratory device Spotchem EZ SP-4430-Arkray-Japan. Bravely, the LDL-C was calculated taking into account the TG, T-Chol and HDL-C concentration and using the equation proposed by Pond et al. (1997). The ratio of LDL-C to HDL-C was calculated. The globulin content was calculated by subtracting total protein from albumin. The A/G ratio (albumin-to-globulin ratio) was also determined.

\section{Statistical calculations}

The experimental data are reported as means and SEM (standard error of the mean). The experimental data were managed using the SPSS V.20 (2011). $\mathrm{P}<0.05$ was used to determine whether or not there were significant differences between values.

\section{RESULTS AND DISCUSSION}

\section{Productive performance}

Along with the study, neither mortality nor symptoms of malnutrition or other disorders were found in both groups. 
In this study, no significant effects $(\mathrm{P}>0.05)$ of dietary millet grain on the productive performance (BW, $\mathrm{ADG}, \mathrm{ADFI}$ and $\mathrm{F}$ : $\mathrm{G}$ ratio) during the experimental period (30d) compared with control (Table 2) were noticed. However, we noticed a slight but not significant improvement on final BW $(+6 \%)$ and $\mathrm{ADG}(+6 \%)$ in the $\mathrm{M}$ diet $v s \mathrm{C}$ diet. The ADFI was also increased by $(+1 \%)$ in the $M$ diet compared with $M$. The Gain: Feed ratio was resembled between treatments.

Our findings agree with other studies where it was found that pigs fed (50\% or more) different types of millet grain have no discernible effect on performance (Adeola and Orban 1995; Lawrence et al., 1995; Bastos et al., 2006; Li et al., 2019; Lefter et al., 2020a; Lefter et al., 2020b; Hassan et al., 2021). Similarly, the use of pearl and finger millets up to $50 \%$ or more instead of maise in the diets of broiler chickens (Bulus et al., 2014; Cisse et al., 2016) or layer's (Issa et al., 2016) resulted in similar performance.

Table 2. Influence of millet grain diet on the growing pigs productive performance

\begin{tabular}{lcccc}
\hline Item & C & M & SEM & P-valu $^{*}$ \\
\hline Pigs, head/group & 20 & 20 & - & - \\
Initial BW (51d), kg & 13.06 & 13.84 & 0.357 & 0.315 \\
Final BW (81d), kg & 31.31 & 33.22 & 0.828 & 0.284 \\
ADG, g/d & 0.608 & 0.646 & 0.019 & 0.368 \\
ADFI, kg/d & 1.287 & 1.387 & 0.725 & 0.350 \\
Gain: Feed ratio, g & 0.47 & 0.46 & 0.11 & 0.260 \\
\hline
\end{tabular}

Note: C-standard diet; M-experimental diet; SEM, standard error of the mean. BW, body weight; ADG, average daily gain; ADFI, average daily feed intake. * Means within rows are not significantly different $(\mathrm{P}>0.05)$.

\section{Plasma metabolic profile}

There is no investigation on millet effects on pigs' plasma biochemical profiles. Our results on plasma biochemical parameters are summarised in Table 3. Plasma metabolites are a valuable biochemical parameter that can reflect health status. Any changes that occur in this biological system can mirror the state of the animal body and by the internal and external factors (Toghyani et al., 2010).

In this research work, the $\mathrm{M}$ diet had no significant effect on pigs' plasma lipid profile; even a slight decrease of the TG (-20\%), T-Chol (-3\%), HDL-C ($2 \%)$ and LDL-C (-2\%) was noticed, as illustrated in Table 3. The lipid levels in the plasma, on the other hand, were within normal limits.

Contrary, several studies (Park et al. 2008; Lee et al., 2010; Nigro et al. 2014) on mice have shown a positive effect of various sorts of millet added in the feed on the metabolism of lipids, as it can rise the HDL-C concentrations, without affecting the concentration of LDL-C. 
The effect of proso millet on the mice plasma levels of HDL-C was studied by Shimanuki et al. (2006), who reported a significant increase in plasma levels of $\mathrm{HDL}_{2}-\mathrm{C}$ fraction, known as a principal factor in protection against coronary heart disease.

Table 3. Influence of millet grain diet on biochemical parameters of growing pigs

\begin{tabular}{|c|c|c|c|c|c|c|}
\hline Item & Parameters & Limits & $\mathbf{C}$ & M & SEM & P-value* \\
\hline \multirow{5}{*}{ Lipid } & $\mathrm{TG}, \mathrm{mg} \mathrm{dL}^{-1}$ & $33-50^{1}$ & 36.1 & 28.9 & 2.64 & 0.179 \\
\hline & $\mathrm{T}$-Chol, $\mathrm{mg} \mathrm{dL}^{-1}$ & $67-367^{2}$ & 105.5 & 102.5 & 2.63 & 0.586 \\
\hline & HDL-C, mg dL-1 & - & 41.5 & 40.8 & 1.63 & 0.826 \\
\hline & LDL-C, mg dL-1 & - & 58.2 & 57.1 & 1.95 & 0.791 \\
\hline & LDL-C/HDL-C ratio & - & 1.4 & 1.4 & 0.07 & 0.934 \\
\hline \multirow{8}{*}{ Protein } & T-Pro, g dL ${ }^{-1}$ & $5.8-8.3^{1}$ & 5.53 & 5.54 & 0.15 & 0.968 \\
\hline & Alb, $\mathrm{g} \mathrm{dL}^{-1}$ & $2.3-4.0^{1}$ & 3.10 & 3.48 & 0.12 & 0.113 \\
\hline & Glob, $\mathrm{g} \mathrm{dL}^{-1}$ & - & 2.18 & 2.43 & 0.13 & 0.368 \\
\hline & $\mathrm{A} / \mathrm{G}$ ratio & - & 1.40 & 1.60 & 0.10 & 0.336 \\
\hline & $\mathrm{UA}, \mathrm{mg} \mathrm{dL}^{-1}$ & - & 0.59 & 0.60 & 0.01 & 0.334 \\
\hline & Cre, $\mathrm{mg} \mathrm{dL}^{-1}$ & $0.8-2.3^{1}$ & 1.35 & 1.34 & 0.03 & 0.828 \\
\hline & T-Bil. mg dL ${ }^{-1}$ & $0-0.5^{1}$ & 0.21 & 0.20 & 0.01 & 0.334 \\
\hline & BUN, $\mathrm{mg} \mathrm{dL}^{-1}$ & $8.2-25^{1}$ & 10.25 & 9.06 & 0.38 & 0.122 \\
\hline \multirow{5}{*}{ Enzyme } & AST, U/L & $18-84^{2}$ & 24.06 & 28.06 & 2.48 & 0.439 \\
\hline & ALT, U/L & $31-75^{1}$ & 50.88 & 59.93 & 1.44 & 0.304 \\
\hline & LDH, UI/L & $380-630^{3}$ & 375.50 & 388.00 & 50.10 & 0.440 \\
\hline & CK, UI/L & $146-870^{2}$ & 634.63 & 649.13 & 23.92 & 0.342 \\
\hline & GGT, UI/L & - & 43.63 & 59.75 & 4.354 & 0.061 \\
\hline \multirow{3}{*}{ Mineral } & $\mathrm{Ca}, \mathrm{mg} \mathrm{dL}^{-1}$ & $6.8-14.8^{2}$ & 14.11 & 14.34 & 0.307 & 0.728 \\
\hline & $\mathrm{Mg}, \mathrm{mg} \mathrm{dL}^{-1}$ & $2-3.5^{1}$ & 2.13 & 2.24 & 0.055 & 0.322 \\
\hline & IP, $\mathrm{mg} \mathrm{dL}^{-1}$ & $5.5-9.3^{1}$ & 9.01 & 9.16 & 0.171 & 0.676 \\
\hline
\end{tabular}

Note: C-standard diet; M-experimental diet. TG (Triglycerides); T-Chol (Total cholesterol); HDL-C (High-density lipoprotein cholesterol); LDL-C (Low-density lipoprotein cholesterol); LDL-C/HDLC ratio (Low-density lipoprotein cholesterol/High-density lipoprotein cholesterol ratio); T-Pro (Total protein); Alb (Albumin); Glob (Globulin); A/G ratio (Albumin/Globulin ratio); UA (Uric acid); Cre (Creatinine); T-Bil (Total bilirubin); BUN (Urea nitrogen); AST (Aspartate aminotransferase); ALT (Alanine aminotransferase); LDH (Lactate dehydrogenase); CK (Creatine kinase); GGT (Gamma glutamyl-transferase); Ca (Calcium); Mg (Magnesium); IP (Inorganic phosphorus). ${ }^{1}$ Merck Veterinary Manual, 2010. ${ }^{2}$ Perri et al., 2017. ${ }^{3}$ Radostits et al., 2000. * Means within rows are not significantly different $(\mathrm{P}>0.05)$.

A benefit of consumption of millet protein concentrate obtained from Japan on plasma lipid levels compared with the standard group was also reported by Nishizawa et al. (2009) in type 2 diabetic mice.

Lower TG and T-Chol levels were seen in diabetes rat pattern fed diets composed of different millet varieties, which were integrated up to $55 \%$ in the mice basal diet (Hegde et al., 2005; Shobana et al., 2010; Park et al., 2011). Furthermore, some millet varieties (e. g. finger, proso) may aid in the 
prevention of heart problems by decreasing blood TG in hyperlipidaemic laboratory animals (Lee et al., 2010).

However, the inconsistent results reported in the in vivo studies and our report regarding lipid metabolism can be related to the technique used, investigational context, or other considerations (Pond et al., 1997; Nishizawa et al., 2009).

Regarding the protein profile, our study results showed that the T-Pro, Alb, Glob, A/G ratio, UA, Cre, T-Bil and BUN were not affected by the M diet $(\mathrm{P}>0.05)$.

Similar to this study, Goodarzi et al. (2011) has evidenced that foxtail millet can be used as a viable option for partial or complete replacement of corn in broiler diets without any adverse effect on protein profile. Also, Kwari et al. (2014) and Medugu et al. (2010) found no difference in plasma protein concentration in the experimental group compared to control when sorghum and millet grains were used in broiler chickens' diets corn diet.

Plasma protein analysis can indicate malnutrition in humans and animals (Li et al., 2021). Low circulating visceral proteins, mostly synthesised in the liver, reflect poor protein and energy intake (Ulrich, 2019). Increased blood protein fractions and the fact that the proso millet diet improved the nutritional state of the piglets were confirmed in a feeding trial carried out by Li et al. (2019) on malnourished pigs.

In our investigation, the plasma protein markers and performance concentrations indicate that the growing pigs fed millet diet did not manifest malnutrition symptoms. Furthermore, blood UA, Cre, BUN and T-Bil are helpful indicators for investigating and evaluating hepatic and renal function (Walker et al., 1990). The apparent lack of any substantial variations in protein content of blood-related to including millet in our experimental diet in the present study further suggested that the piglets were in good health.

Several studies (Radostits et al., 2000; Nishizawa et al., 2002; Karlsson et al., 2009; Hyder et al., 2013; Jurisic et al., 2015) reported that the AST, ALT, LDH, CK and GGT enzymes are ubiquitously identified in biological system (e.g., muscular, hepatic, cardiac and vascular tissue) and serve as an important checkpoint of tissues damaged (Rej, 1978; Reichling and Kaplan, 1988). Pigs subjected to pathological changes in different organs due to various factors, including feed or feed components, respond significantly to plasma enzyme elevation (Lykke et al., 2013).

In this trial, as an indicator of hepatic or renal function, clinical biochemistry revealed no difference in AST, ALT, LDH and GGT concentration in the pigs fed millet diet. Furthermore, a similar concentration of LDH and AST enzymes in the liquid fraction of the blood indicates that the millet diet does not contribute to multiorgan dysfunction. No significant differences were seen between pigs fed millet and control diet for CK, as key enzyme of musculoskeletal system (e. g. cardiac muscle) damage (Jurisic et al., 2015). 
Proso millet and other millets are a good source of various health-related nutrients, including magnesium and phosphorus, and could be used to prevent malnutrition caused by mineral deficiencies (Habiyaremye et al., 2017; Krishnan and Meera, 2018). However, as in the case of other cereals, the antinutritional factors could reduce the availability of the minerals (Abdelrahman et al., 2005).

In this trial, the concentrations of $\mathrm{Ca}, \mathrm{Mg}$ and IP in the plasma were not influenced by the addition of millet in the diet. The values obtained were within physiological limits. Therefore, we can assume that the hydrothermal processing, granulation of the diets used in our study, remove the major antinutritional compounds and improve micronutrients bioavailability.

According to Goodarzi et al. (2011), foxtail millet could replace 33, 66, or 100 per cent of corn in the broiler chickens feed formula without affecting the mineral content in the blood.

\section{CONCLUSION}

The present study results suggest that the $25 \%$ millet added to the growing pigs' diet had not determined a decline of the growth performance; on the contrary, a slight increase was noticed. Notably, the findings on blood indices suggest that this feed formula had no negative impact on growing pigs health; the values ranged within the reference limits specific to the physiological category.

\section{ACKNOWLEDGEMENTS}

The Ministry of Agriculture and Rural Development of Romania funded this trial through Sectorial Project ADER 9.1.4.

\section{REFERENCES}

Abdelrahman, S.M., Elmaki, H.B., Idris, W.H., Babiker, E.E., Tinay, A.H.E. 2005. Antinutritional factors content and minerals availability of pearl millet (Pennisetum glaucum) as influenced by domestic processing methods and cultivation. J Food Technol. 3, 397-403.

Adeola, O., Orban, J.I. 1995. Chemical composition and nutrient digestibility of pearl millet (Pennisetum glaucum) fed to growing pigs. J Cereal Sci. 22, 177-184.

Bastos, A.O., Moreira, I., Furlan, A.C., Oliveira, G.C., de Fraga, A.L., Sartori, I.M. 2006. Effect of feeding increasing levels of pearl millet (Pennisetum glaucum (L.) R. Brown) grain for growing and finishing pigs. Rev Bras Zootec. 35 (1), 98-103. 
Bulus, E., Ibe, E., Dodo, S., Makinde, I.S.O. 2014. Performance of broiler chickens fed two varieties of guinea corn and millets as replacement for maise. Iran J Appl Anim Sci. 4 (3), 541-547.

Council, N.R. Nutrient Requirements of Swine: Eleventh Revised Edition; The National Academies Press: Washington, DC, USA, 2012; ISBN 978-0309-22423-9.

Cisse, R.S., Hamburg, J.D., Freeman, M.E., Davis, A.J. 2016. Using locally produced millet as a feed ingredient for poultry production in SubSaharan Africa. J Appl Poultry Res. 26 (1), 9-22.

Dipnarayan, S., Channabyre, M.V.C., Lalit, A., Manjusha, V., Kailash, C.B. 2016. Genetic and genomic resources of small millets. CRC Crit Rev Plant Sci. 35(1), 56-79.

Directive (EU) No. 63 (2010). Official Journal of the European Union, L 276, 33-79.

Goodarzi, B.F., Samie, A.H. Edriss, M.A., Khorvash, M., Sadeghi, G., Van Kessel, A., Zentek, J. 2011. Replacement of corn in the diet of broiler chickens using foxtail millet produced by 2 different cultivation strategies. Poult Sci. 90, 2817-2827.

Hăbeanu, M. Lefter, N.A., Gheorghe, A., Untea, A., Ropotă, M., Grigore, D-M., Varzaru I., and Toma, S.M. 2019. Evaluation of performance, nitrogen metabolism and tissue composition in barrows fed an n-3 PUFA-rich diet. Animals. 9 (234), 2-13.

Habiyaremye, C., Matanguihan, J.B., Guedes, J.D'A., Ganjyal, G.M., Whiteman, R.M., Kidwell, K.K., Murphy, K.M. 2017. Proso millet (Panicum miliaceum L.) and its potential for cultivation in the Pacific Northwest, U.S.: A Review. Front Plant Sci. 7 (1961), 1-17.

Hassan, Z.M., Sebola, N.A. and Mabelebele, M. 2021. The nutritional use of millet grain for food and feed: a review. Agric \& Food Secure. 10 (16), 2-16.

Hegde, P.S., Namakkal, S., Rajasekaran, T.S.,,Chandra, T. 2005. Effects of the antioxidant properties of millet species on oxidative stress and glycemic status in alloxan-induced rats. Nut Research. 25, 1109-1120.

Hellwing, A., Louise, F., Tauson, A.H., Skrede, A. 2007. Blood parameters in growing pigs fed increasing levels of bacterial protein meal. Brief communication. Acta Vet Scand. 49 (33), 1-4.

Hyder, M.A., Hasan, M., and Mohieldein, A.H., 2013. Comparative levels of ALT, AST, ALP and GGT in liver associated diseases. Euro J Exp Bio. 3 (2) 280-284.

Issa, S., Jarial, S., Brah, N., Harouna, L. 2016. Are millet and sorghum good alternatives to maise in layer's feeds in Niger, West Africa. Indian J Anim Sci. 86 (11), 1302-1305. 
Jurisic, V., Radenkovic, S., and Konjevic, G. 2015. The actual role of LDH as tumor marker, biochemical and clinical aspects. Adv Exp Med Biol, 867, 115-124.

Karlsson, M., Satas, S., Stone, J., Porter, H., Thoresen, M. 2009. Liver enzymes cannot be used to predict liver damage after global hypoxia-ischemia in a neonatal pig model. Neonatology. 96, 211-218.

Krishnan, R., Meera, M. S. 2018. Pearl millet minerals: effect of processing on bioaccessibility. J Food Sci Technol. 55 (9), 3362-3372.

Kwari, I.D., Igwebuike, J.U., Taiya, H., Muhammad, A.A. and Raji, A.O. 2014. Hematology and serology of broiler chickens fed maise, sorghum and millet and, their combinations in the semi-arid zone of Nigeria. Int J Sci Nat. 5 (2), 319-322.

Lawrence, B.V., Adeola, O., and Rogler, J.C. 1995. Nutrient digestibility and growth performance of pigs fed pearl millet as a replacement corn. J Anim Sci. 73, 2026-2032.

Lee, S.H., Chung, I-M., Cha, Y-S., Parka, Y. 2010. Millet consumption decreased serum concentration of triglyceride and C-reactive protein but not oxidative status in hyperlipidemic rats. Nutr Res. 30, 290-296.

Lefter, N.A., Hăbeanu, M., Gheorghe, A., Idriceanu, L. 2020a. Preliminary research on growth response and health status of piglets fed millet grain as a partial replacement for triticale. Sci Papers Ser D Anim Sci. LXIII (1), 135-141.

Lefter, N.A., Hăbeanu, M., Gheorghe, A., Idriceanu, L., Cirebea M. 2020b. Use of millet grain in weaning pigs diet: effects on performance and health status. Arch Zootech. 23 (2), 143-154.

Li, X., Yan, H., JunLi, R., Yanni, S., Songling, L., Lianqiang, C., Xi, P., Xiaoshuang, D. 2019. Millet-based supplement restored microbiota 1 diversity of acute 2 undernourished pigs. Bio Rxiv. 1-26.

Li, X., Hui, Y., Leng, B., Ren, J., Song, Y., Che, L., Peng, X., Huang B., Liu, S., Li, L., Nielsen, D.S., Li, Y., Dai, X., Zhao, S. 2021. Millet-based supplement restored gut microbial diversity of acute malnourished pigs. PLoS One. 16 (4), e0250423.

Lu, H., Zhang, J., Liu, K., Wu, N., Li, Y., Zhou, K., Ye, M., Zhang, T., Zhang, H., Yang, X., Shen, L., Xu, D. and Li, Q. 2009. Earliest domestication of common millet (Panicum miliaceum) in East Asia extended to 10,000 years ago. PNAS USA. 106 (18), 7367-7372.

Luo, Z., Zhu, W., Guo, Q., Luo, W., Zhang, J., Xu, W., Xu, J. 2016. Weaning induced hepatic oxidative stress, apoptosis, and aminotransferases through MAPK signaling pathways in piglets. Oxid Med Cell Longev. ID 4768541, 1- 10.

Lykke, M., Hother, A-L., Hansen, F.F., Friis, H., Mølgaard, C., Michaelsen, C.F., Briend, A., Larsen, T., Sangild, P.S., Thymann, T. 2013. Malnutrition 
induces gut atrophy and increases hepatic fat infiltration: studies in a pig model of childhood malnutrition. Am J Transl Res. 5 (5), 543-554. Mathanghi, S.K., Kanchana, S., Perasiriyan V. 2020. Pinnacles of Proso millet (Panicum miliaceum L.): A nutri millet. Trop Plant Res. 7 (1), 238-244. Medugu, C.I., Kwari, I.D., Igwebuike, J., Nkama,, I., Mohammed, I.D., Hamaker, B. 2010. Carcass and blood components of broiler chickens fed sorghum or millet as replacement for maise. Agric Biol J North Am. 1 (3), 326329.

Merck Co. 2010. The Merck Veterinary Manual, 10 ${ }^{\text {th }}$ (Eds.), Merck Co., Inc., Kenilworth, NJ, USA.

Nigro, E., Scudiero, O., Monaco, M.L, Palmieri, A., Mazzarella, G., Costagliola, C., Bianco, A., Daniele, A. 2014. New insight into adiponectin role in obesity \& obesity-related diseases. BioMed Res. Int. 1-14.

Nishizawa, N., Sato, D., Ito, Y., Nagasawa, T., Hatakeyama, Y., Choi, M-R., Choi, Y-Y., Wei, Y. M. 2002. Effects of dietary protein of proso millet on liver injury induced by D-galactosamine in rats. Biosci Biotechnol Bioch. 66 (1), 92-96.

Nishizawa, N., Togawa, T., Park, K-O., Sato, D., Miyakoshi, Y., Inagaki, K., Ohmori, N., Ito, Y. and Nagasawa, T. 2009. Dietary Japanese millet protein ameliorates plasma levels of adiponectin, glucose and lipids in type 2 diabetic mice. Biosci Biotechnol Bioch. 73 (2), 351-366.

Park, K.O., Ito, Y., Nagasawa, T., Choi, M.R., Nishizawa, N. 2008. Effects of dietary Korean proso-millet protein on plasma adiponectin, HDL cholesterol, insulin levels, \& gene expression in obese type 2 diabetic mice. Biosci Biotechnol and Biochem. 72, 2918-2925.

Park, M-Y., Jang, H-H., Kim, J.B., Yoon, H.N., Lee, J-Y., Lee, Y-M., Kim J-H., Park DS. 2011. Hog millet (Panicum miliaceum L.) supplemented diet ameliorates hyperlipidemia and hepatic lipid accumulation in C57BL/6J-ob/ob. mice. Nutr Res Pract. 5 (6), 511-519.

Perri, A.M., O’Sullivan, T.L., Harding, J.C.S, Wood, R.D., Friendship, R.M. 2017. Haematology and biochemistry reference intervals for Ontario commercial nursing pigs close to the time of weaning. Can Vet J. 58(4), 371-376.

Pond, W.G., Su, D.R., Mersmann, H.J. 1997. Divergent concentrations of plasma metabolites in swine selected for seven generations for high or low plasma total cholesterol ${ }^{1,2}$. J Anim Sci. 75, 311-316.

Radostits, O., Gay, C., Hinchcliff, K., Constable, P. 2000. A textbook of the diseases of cattle, horses, sheep, pigs and goats. Veterinary medicine, 9th (Edn.) Saunders, London, pp. 1819-1822.

Reichling, J.J., Kaplan, M.M. 1988. Clinical use of serum enzymes in liver disease. Dig Dis Sci. 33, 1601-1614.

Rej, R. 1978. Aspartate aminotransferase activity and isoenzyme proportions in human liver tissues. Clin Chem. 24, 1971-1979. 
Scherer, P.E. 2006. Adipose tissue: from lipid storage compartment to endocrine organ. Diabetes. 55, 1537-1545.

Schwartz, R., Conley, C.L. 2020. Blood. Encyclopædia Britannica https://www.britannica.com/science/blood-biochemistry.

Shimanuki, S., Nagasawa, T. \& Nishizawa, N. 2006. Plasma HDL subfraction levels increase in rats fed proso-millet protein concentrate. Med Sci Monit. 12 (7), 221-226.

Shobana, S., Harsha, M.R., Platel, K., Srinivasan, K., Malleshi, N.G. 2010. Amelioration of hyperglycemia and its associated complications by finger millet (Eleusine coracana L.) seed coat matter in streptozotocininduced diabetic rats. Brit J Nutr. 104, 1787-1795.

Singh, S. Chauhan, E.S. 2019. Role of underutilised millets and their nutraceuticals importance in the new era. A review. IJSRR. 8 (2), 28442857.

SPSS .2011. Statistics v. 20.0., IBM, SPSS, Inc., USA.

Toghyani, M., Tohidi, M., Gheisari, A.A. 2010. Performance, immunity, serum biochemical and hematological parameters in broiler chicks fed dietary thyme as alternative for an antibiotic growth promoter. Afr J Biotechnol. 9, 6819e25.

Ulrich, K. 2019. Review nutritional laboratory markers in malnutrition. J Clin Med. 8 (775), 2-11.

Walker, H., Kenneth, M.D., Dallas, W., Hall, M.D., Hurst, J.W. 1990. MD. Clinical Methods, 3rd (Ed.). The History, Physical, and Laboratory Examinations. Boston: Butterworths ed. pp. 1238-1378.

Whittaker, A., Dinu, M., Cesari, F., Gori, A.M., Fiorello, C., Becatti, M., Casini, A., Marcucci, R., Benedettelli, S., Sofi, F., 2017. A Khorasan wheat-based replacement diet improves the risk profile of patients with type 2 diabetes mellitus (T2DM): A randomised crossover trial. Eur J Nutr. $56,1191-1200$. 